\title{
Produced Water Treatment Planning Using Corrugated Plate Interceptor and Ultra Filtration for Water Recycling
}

\author{
Novena Lany Pangestu1, Nurulbaiti Listyendah Zahra², Ariyanti Sarwono ${ }^{3}$, \\ I Wayan Koko Suryawan ${ }^{4 *}$ \\ ${ }^{1,2,3,4}$ Faculty of Infrastructure Planning, Department of Environmental Engineering, Universitas Pertamina, Komplek \\ Universitas Pertamina, Jalan Sinabung II, Terusan Simprug, Jakarta 12220, Indonesia. \\ *Koresponden email: i.suryawan@ universitaspertamina.ac.id
}

Received: August 30, 2021

Accepted: October 6, 2021

\begin{abstract}
Produced water generated by the oil and gas industry, when treated properly, will produce water that is ready to be reused, such as for watering plants. This planning is done by treating the produced water with Corrugated Plate Interceptor (CPI) and Ultra Filtration units. This research aims to analyze the design details needed in the recycling of produced water with CPI and Ultra Filtration units. After determining the design criteria used, the dimensions for each unit are obtained. Data was collected using secondary data directly from the study site and quantitative method was used for data analysis. The land area for one CPI unit requires $55 \mathrm{~m}^{2}$ with a volume of $110 \mathrm{~m}^{3}$. The Reynolds number and Froude number for CPI units meet the design criteria with 419.8 and 0.24 , respectively. The ultra-filtration unit was selected with a Flux specification of $0.15 \mathrm{~m}^{3} / \mathrm{m}^{2}$.hour with an operational duration of 24 hours. The results of processing with the CPI unit can at least produce oil and fat effluent of $0.038 \mathrm{mg} / \mathrm{L}$, with the threshold for water quality is $1 \mathrm{mg} / \mathrm{L}$. Produced water treatment planning with CPI configuration and UF membrane with storage tank requires a total land area of $63.97 \mathrm{~m}^{2}$.
\end{abstract}

Keywords: produced water, corrugated plate interceptor, ultra-filtration, water recycling, oil \& gas industry

\begin{abstract}
Abstrak
Air terproduksi yang dihasilkan industri migas jika diolah dengan baik akan menghasilkan air yang siap digunakan kembali seperti untuk menyiram tanaman. Perencanaan ini dilakukan dengan mengolah air terproduksi dengan unit Corrugated Plate Interceptor (CPI) dan Ultra Filtrasi. Tujuan penelitian ini adalah untuk menganalisa detail desain yang dibutuhkan dalam daur ulang air terproduksi dengan unit CPI dan Ultra Filtrasi. Setelah menentukan kriteria desain yang digunakan, maka didapatkan dimensi untuk masingmasing unit. Pengumpulan data dilakukan dengan menggunakan data sekunder langsung dari lokasi studi dan metode analisa data dilakukan dengan kuantitatif. Luas lahan untuk satu unit CPI membutuhkan $55 \mathrm{~m}^{2}$ dengan volume sebesar $110 \mathrm{~m}^{3}$. Bilangan Reynold dan Bilangan Froude untuk unit CPI dapat memenuhi kriteria desain dengan nilai 419,8 dan 0,24, masing-masing. Unit ultra filtrasi dipilih dengan spesifikasi Fluks sebesar $0,15 \mathrm{~m} 3 / \mathrm{m}^{2}$.jam dengan durasi operasional 24 jam. Hasil pengolahan dengan unit CPI dapat setidaknya menghasilkan hasil efluen minyak dan lemak sebesar $0,038 \mathrm{mg} / \mathrm{L}$, dimana ambang batas untuk kualitas air adalah $1 \mathrm{mg} / \mathrm{L}$. Perencanaan pengolahan air terproduksi dengan konfigurasi CPI dan membran UF dengan tangki penyimpanan membutuhkan total luas lahan $63,97 \mathrm{~m}^{2}$.

Kata Kunci: air terproduksi, daur ulang air, corrugated plate interceptor, ultra-filtration, industri minyak dan gas
\end{abstract}

\section{Introduction}

Oil and gas industry activities in the upstream sector are essential activities that can potentially cause pollution and environmental damages. In the oil and gas industry, upstream activities are considered the primary key, especially exploration. Exploration activities carried out by the oil and gas industry produce fluids containing oil and gas, sludge and co-produced water. Produced water management can be done using several methods, one of them is injection. In the injection method, the produced water is pumped back into a formation in the soil [1]. However, the characteristics of the produced water must match the features of the construction, and not all appearances can accept the injection of produced water in substantial quantities. In addition, the injection method is expensive and can induce seismicity of earthquake by human activities [2]. 
In oil and gas rock formations, the produced water is groundwater with hydrocarbons and becomes waste from drilling production [3]. Produced water is always found along with oil. This water is slightly acidic and lies beneath the hydrocarbons in the formation or reservoir. Produced water is water that comes to the surface as a by-product of oil and gas drilling activities. Its composition is influenced by the characteristics of the reservoir where the water is located. Produced water is a naturally occurring groundwater and includes water previously injected during good maintenance and chemicals added during production. Another source of produced water is from backflow which returns to the surface due to hydraulic fracking of the well.

The utilization of produced water can reduce water discharge to the environment and provide new clean water sources for companies. Based on Government Regulation (PP) Number 22 of 2021 concerning Implementation of Environmental Protection and Management (attachment VI), water watering crops, fish farming, and other uses require the same water quality that are categorized into class III water. Class III water quality were used as a reference for the design of produced water because the produced water contains high enough oil and fat, and needs to be set aside. Produced water treatment is also carried out to improve environmental performance through implementing clean production by reusing produced water for watering plants. Wastewater discharged into rivers usually impacts human health and ecological damage [4] [5] [6][7]. Clean production is one indicator of inefficiency that focuses on reducing waste generation and utilizing waste through recycling. According to Name [8], the concept of reuse will replace the notion of produced water waste as a non-profit sector or "cost" to waste as profit. To implement clean production, it necessitates the company to participate in supporting sustainable development.

The oil processing unit, commonly used, is the Corrugated Plate Interceptor (CPI). CPI is an improved form of PPI as it requires a smaller area, easier sediment handling and cheaper than PPI [9]. The plate is positioned at an angle of $45^{\circ}$ and the main components of the CPI separator are the separator tank, CPI plate, weir for oil and effluent, tank cover, solid hopper, inlet and outlet nozzle. The advantages of the CPI unit are no moving parts, less land required than other separators, high separation efficiency, low maintenance, low operating costs, short detention time, continuous operation, unaffected by weather and temperature conditions, resistance to shock, and slug loads and equipped with an inlet chamber as an inlet distributor. Improving the quality of CPI-treated water can be achieved with an ultra-filtration unit. A pretreatment before membrane filtration unit can reduce the possible fouling [10] with a CPI Unit. Thus, the purpose of this study is to obtain a production water treatment design following the quality standards of Government Regulation (PP) Number 22 of 2021 with CPI and ultrafiltration membranes.

\section{Material and Methods \\ Data Collection}

Data collection is needed to support the process planning. Data collection method is determined based on the data type. Both primary and secondary data were obtained [11]. Primary data were collected from direct measurements or observation, while secondary data were readily available data from other sources such as journals, documents and others. The primary data in this design is the existing conditions in the PT. XY. Secondary data includes data on the characteristics of produced water in PT. XY from PHE's Environmental Management Plan and Environmental Monitoring Plan Kampar-Siak document. The main parameters are those regulated in Permen LH No. 19 the Year 2010, specifically for produced water. Parameters like Chemical Oxygen Demand (COD), oils and fats, temperate Government Regulation (PP) Number 22 of 2021 were used as references for water quality limits.

Table 1. Design criteria for Corrugated Plate Interceptor (CPI) units

\begin{tabular}{|c|c|c|c|c|}
\hline Parameters & Symbol & Value & Unit & Source \\
\hline Unit depth & $\mathrm{H}$ & $0.9144 \leq \mathrm{H} \leq 2,438$ & $\mathrm{~m}$ & \multirow{4}{*}[12]{} \\
\hline Unit Width & $\mathrm{L}$ & $1.8288 \leq \mathrm{L} \leq 6.096$ & $\mathrm{~m}$ & \\
\hline Horizontal speed & VH & $\mathrm{VH} \leq 0.9144$ & $\mathrm{~m} /$ minute & \\
\hline Reynolds number & Nre & Nre $\leq 1$ & & \\
\hline Unit depth: unit width & $\mathrm{H}: \mathrm{L}$ & $0.3-0.5$ & & \multirow{5}{*}{ [13] } \\
\hline long forebay & Pf & minimal $1 / 3 \mathrm{P}$ & $\mathrm{m}$ & \\
\hline afterbay length & $\mathrm{Pa}$ & $1 / 4 \mathrm{P}$ & $\mathrm{m}$ & \\
\hline Oil barrier & $0,25 \mathrm{P}$ dari outlet & & & \\
\hline CPI Plate & & & & \\
\hline Distance between plates & Hap & $0,5-2$ & inch & \multirow{3}{*}{ [9] } \\
\hline $1.27-5.08$ & $\mathrm{~cm}$ & & & \\
\hline Plate angle & $\theta$ & $45-60$ & level & \\
\hline Plate free area : unit depth & $\begin{array}{c}\text { ha: H } \\
\text { ha }\end{array}$ & $\begin{array}{l}1: 5 \\
\geq 12\end{array}$ & inch & {$[14]$} \\
\hline
\end{tabular}




\begin{tabular}{|c|c|c|c|}
\hline $\begin{array}{l}\text { The distance between the } \\
\text { plate and the roof of the } \\
\text { separator }\end{array}$ & & $\geq 30.48$ & $\mathrm{~cm}$ \\
\hline $\begin{array}{c}\text { Distance between plate and } \\
\text { separator base }\end{array}$ & hb & $\begin{array}{c}6 \\
15.24\end{array}$ & $\begin{array}{l}\text { inch } \\
\mathrm{cm}\end{array}$ \\
\hline
\end{tabular}

\section{Planning}

Calculation of the design of the selected processing plant circuit includes detailed design specifications and dimensional. This detailed calculation is used to support the stage-making technical drawings of the installation. Each analysis will be adjusted to the criteria design to determine the feasibility of produced water treatment plant design. The design criteria for the CPI unit and ultrafiltration unit can be seen in Table 1 and Table 2 , respectively

Table 2. Design criteria for ultrafiltration membrane units

\begin{tabular}{ccc}
\hline Parameter & Value & Unit \\
\hline Flux rate & $0.03-0.17$ & $\mathrm{~m}^{3} / \mathrm{m}^{2}$.hour \\
Pressure & $20-200$ & $\mathrm{kPa}$ \\
Membrane/module area & $8-70$ & $\mathrm{~m}^{2} / \mathrm{modul}^{-}$ \\
Number of modules/shelves & $2-300$ & \\
Module dimensions & & $\mathrm{mm}$ \\
- diameter & $100-300$ & $\mathrm{~m}$ \\
- long & $1-6$ & minute \\
& $1-5$ & minute \\
\hline
\end{tabular}

Source: [15]

\section{Results and Discussion}

The design of the CPI unit, ultrafiltration membrane, and reservoir (Figure 1) refers to the applicable references and design criteria in order to achieve technical feasibility of unit. The Corrugated Plate Interceptor (CPI) unit, aimed to remove oil and grease, will be designed in one unit and is 6.1 meters from pit-04. The produced water will be pumped to the CPI unit at a maximum flow rate of $0.0168 \mathrm{~m}^{3} / \mathrm{s}$. The CPI unit will be built in the ground with concrete coating. The inlet pipe is designed to be submersible or underground. The planning criteria for ultrafiltration membranes can be seen in Table 1.

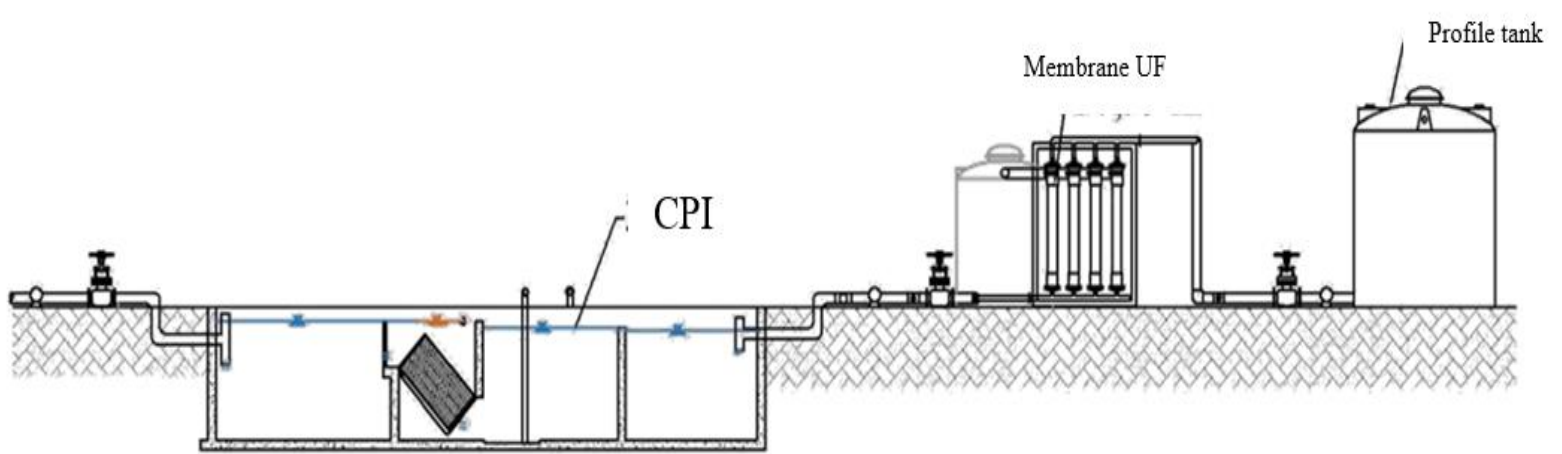

Figure 1. Schematic design of Produced Water Treatment Using CPI and Ultrafiltration membranes source: the results of the author's interpretation and analysis

Based on the data obtained from planning, the design criteria literature, detailed calculations were carried out to design the CPI unit. Planning data used in the CPI unit is presented in Table 3.

Table 3. Analysis result of planning data used in planning the CPI unit

\begin{tabular}{lllll}
\hline Parameter & Symbol & Value & Unit & Design Criteria \\
\hline Produced water discharge & Qi & 1454,09 & $\mathrm{~m}^{3} / \mathrm{day}$ & \\
Produced water density & $\rho \mathrm{w}$ & 995 & $\mathrm{~kg} / \mathrm{m}^{3}$ & \\
Concentration of Demand and & & 16,28 & $\mathrm{mg} / \mathrm{L}$ & 1 \\
Fat & & 287,8 & $\mathrm{mg} / \mathrm{L}$ & 50 \\
COD concentration & & 879,9 & $\mathrm{~kg} / \mathrm{m}^{3}$ & \\
Oil density & po & & & \\
\hline
\end{tabular}




\begin{tabular}{|c|c|c|c|c|}
\hline Oil particle diameter & $\mathrm{d}$ & 70 & $\mu \mathrm{m}$ & \multirow[b]{4}{*}{$\begin{array}{l}0,9144 \leq \mathrm{H} \\
\leq 2,438\end{array}$} \\
\hline Dynamic viscosity of water & $\mu \mathrm{w}$ & $0,769 \times 10-3$ & $\mathrm{~kg} / \mathrm{m} . \mathrm{s}$ & \\
\hline Kinematic viscosity of water & $\nu \mathrm{W}$ & $0,772 \times 10-6$ & $\mathrm{~m}^{2} / \mathrm{s}$ & \\
\hline Unit depth & $\mathrm{H}$ & 2 & $\mathrm{~m}$ & \\
\hline Unit depth: unit width & $\mathrm{H}: \mathrm{L}$ & 0.36 & $0,3-0,5$ & \\
\hline Unit Width & $\mathrm{L}$ & 5,5 & $\mathrm{~m}$ & \\
\hline Inlet oil and fat concentration & $\mathrm{Ci}$ & 16,28 & $\mathrm{mg} / \mathrm{L}$ & \\
\hline Unit efficiency & $\mathrm{E}$ & 99,77 & $\%$ & \\
\hline temperature & $\mathrm{T}$ & 32 & ${ }^{\circ} \mathrm{C}$ & \\
\hline CPI Plate & & & & \\
\hline Plate angle & $\theta$ & 45 & degree & $30-60$ \\
\hline $\begin{array}{l}\text { Distance between plate and } \\
\text { separator base }\end{array}$ & $\mathrm{hb}$ & 15,24 & $\mathrm{~cm}$ & \\
\hline Pack plate width & Lp & 0,71 & $\mathrm{~m}$ & \\
\hline Plate length & $\mathrm{Pp}$ & 2,75 & $\mathrm{~m}$ & \\
\hline Number of pack plates & & 2 & unit & \\
\hline Distance between plates & Splat & 3,95 & $\mathrm{~cm}$ & \\
\hline
\end{tabular}

Source: The results of the author's interpretation and analysis

The plates are arranged into two plate packs and placed at an angle of $45^{\circ}$. The determination of the CPI plate used refers to the calculations from ref. [16] and ref. [17]. The separated oil and fat will be sent to the shipping tank unit at PT. XY PHE Kampar-Siak. Oil and grease accumulated on the surface of the CPI tank will be removed using an oil skimmer. Prior taken to the shipping tank, oil and grease will be accommodated in an oil storage tank having a width dimension of 0.7 meters and a length of 6.8 meters. The depth of the oil reservoir follows the depth of the CPI unit, i.e. by 2 meters. Detailed calculations for CPI units is presented in Table 4.

Table 4. Calculation of details CPI units according to the characteristics of PT XY

\begin{tabular}{|c|c|}
\hline Planning & $n$ \\
\hline $\begin{array}{l}\text { Calculation of } \\
\text { CPI units }\end{array}$ & $\begin{array}{l}\text { - } \text { Influent CPI units: } \\
\text { - } \mathrm{Qi}=1454.09 \mathrm{~m} 3 / \text { day }=60.59 \mathrm{~m}^{3} / \mathrm{hour}=1.01 \mathrm{~m}^{3} / \mathrm{minute} \\
\text { - } \text { Calculating the rate of floatation of oil and grease }(\mathrm{Vt}) \\
\text { - } \mathrm{Vt}=\mathrm{g}(\rho w-\rho o) d 2 / 18 . \mu w==0.0004 \mathrm{~m} / \mathrm{s}=0.024 \mathrm{~m} / \mathrm{min} \\
\text { - } \text { Calculating Reynolds number }(\mathrm{Nre}) \\
\text { Nre }=\mathrm{Vt} . d / \vartheta w=(0.0004 \mathrm{~m} / \mathrm{s})(70 \times 10-6 \mathrm{~m}) / 0.772 \times 10-6 \mathrm{~kg} / \mathrm{m} . \mathrm{s}=0.036 \text { (meets design } \\
\text { criteria, Nre } 1) \\
\text { - } \text { Calculate detention time }(\mathrm{td}) \\
\text { - } \quad \text { td }=\mathrm{H} / \mathrm{Vt}=2 \mathrm{~m} / 0.024 / \mathrm{menit}=83.39 \mathrm{~min} \\
\text { - } \text { Calculating the initial volume }(\text { Volleyball }) \\
\text { - } \text { Calleyball }=\mathrm{Qi} \times \mathrm{x} \text { td }=(1.01 \mathrm{~m} 3 / \mathrm{min}) \times 83.39 \mathrm{~min}=84.21 \mathrm{~m} 3 \\
\text { removal efficiency is determined of } 99.77 \% \text { which is the maximum number of } \\
\text { - } \mathrm{E}=0.9977 \times(16.28 \mathrm{mgL})(1.013 / \mathrm{min})-(1.013 / \mathrm{min}) /(16.28 \mathrm{mg} / \mathrm{L})(1.013 / \mathrm{min}) \\
\text { Co }=0.038 \mathrm{mg} / \mathrm{L}\end{array}$ \\
\hline $\begin{array}{l}\text { Calculates } \\
\text { horizontal flow } \\
\text { velocity }(\mathrm{VH}), \\
\text { with a width of } \\
5.5 \mathrm{~m} \text { (criteria = } \\
1.83 \mathrm{~m} \leq \mathrm{L} \leq 6.09 \\
\mathrm{~m}) \\
\text { and a depth of } 2 \\
\mathrm{~m}(\text { criteria }= \\
0.9144 \mathrm{~m} \mathrm{H} \\
2,438 \mathrm{~m}) \text { and an } \\
\mathrm{H}: \mathrm{L} \text { ratio of } 0.36 \\
(\text { criteria }= \\
0.3-0.5)\end{array}$ & 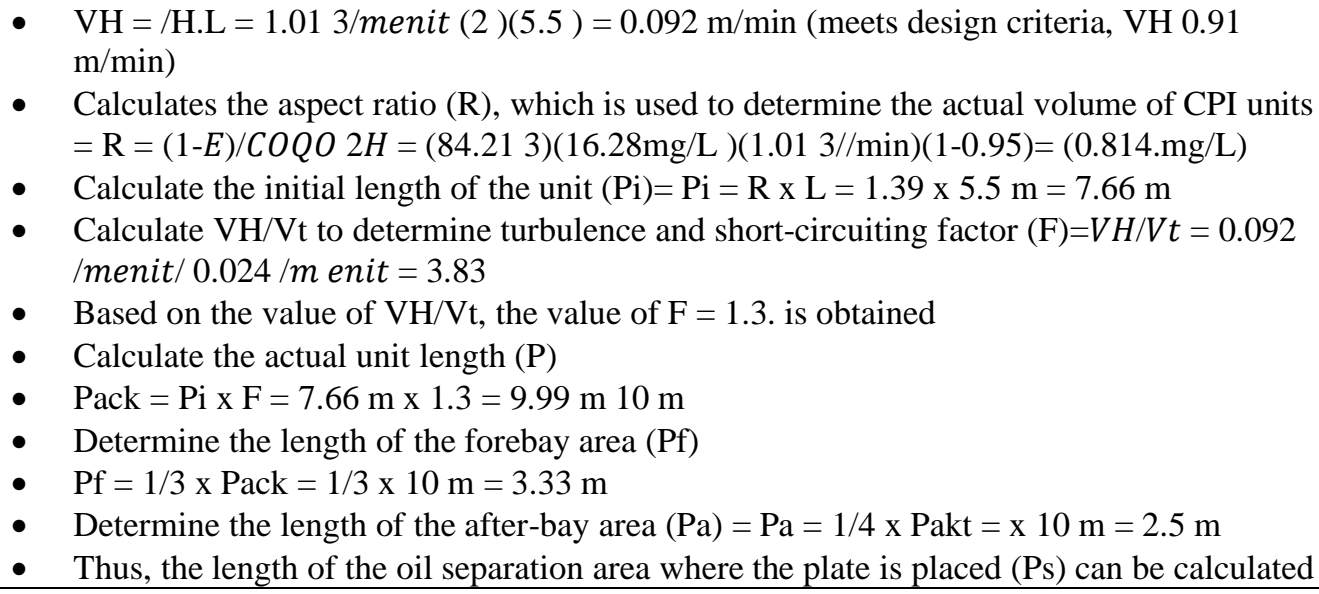 \\
\hline
\end{tabular}




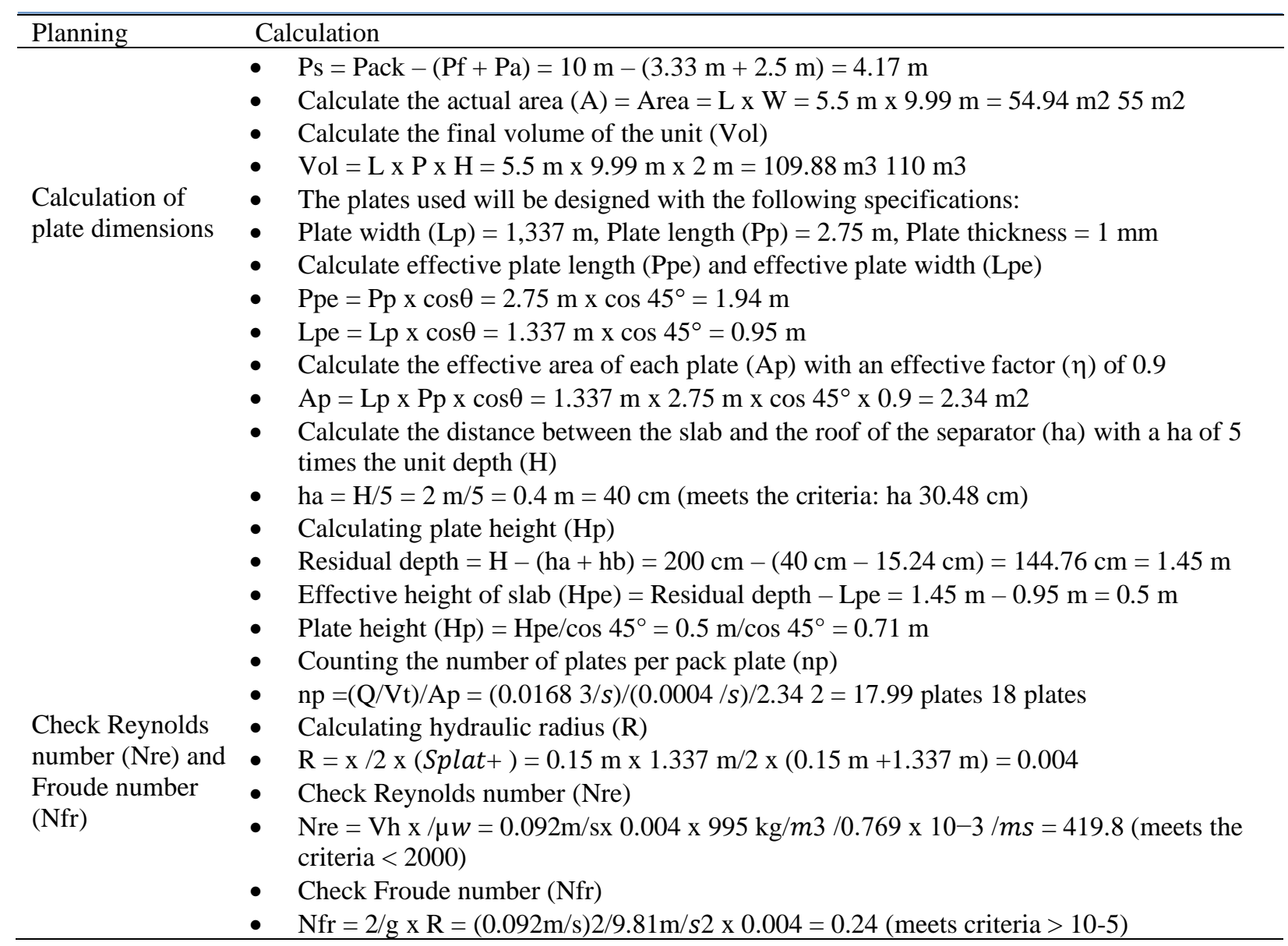

Source: Source: The results of the author's interpretation and analysis

According to the National Standardization Agency [18], a Reynolds number less than 2000 indicates that the flow in the plate is laminar in order to ensure the smoothness of oil deposition process. The schematic representation of CPI processing according to detailed calculations is depicted in Figure 2.

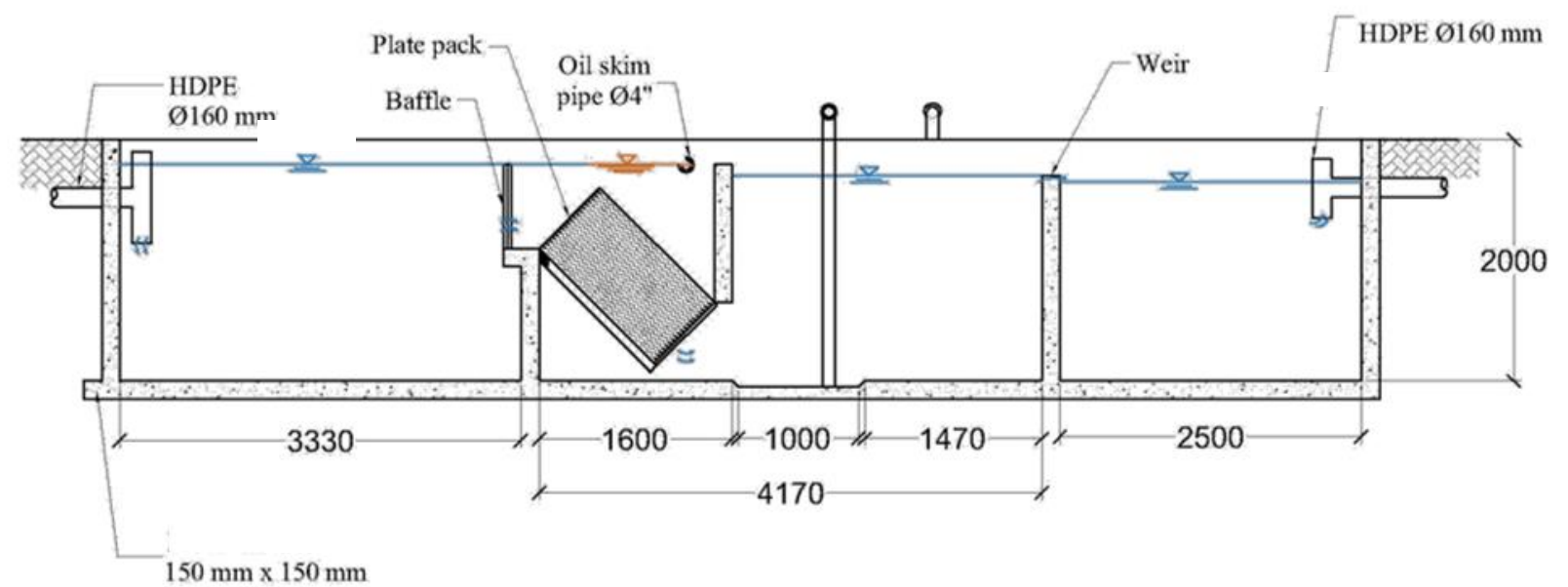

Figure 2. Schematic design of produced water treatment with CPI unit Source: The Results of the Author's Interpretation and Analysis

The ultrafiltration membrane unit design refers to the design criteria. The selected ultrafiltration membrane is made of polyvinylidene fluoride (PVDF) with a hollow fiber module. This type of membrane was chosen because it is widely used in produced water treatment, such as [19] research. The design of the ultrafiltration membrane is adapted to the membrane technology available in the market. The type of ultrafiltration membrane used is the pressurized ultrafiltration membrane hollow fiber module model. This membrane was selected because it meets the calculation of the required membrane area and discharge. According to membrane specifications, each module is able to treat water with temperature up to $40^{\circ} \mathrm{C}$ and 
discharge range from 45 to $180 \mathrm{~m}^{3} /$ day. The detailed planning of the ultrafiltration membrane unit are presented in Table 5 and Figure 3.

Table 5. Calculation of details membrane ultrafiltration units according to the characteristics of PT XY

\begin{tabular}{llll}
\hline Parameters & Planning Value & Units & Design Criteria \\
\hline Flux (J) & 0,15 & $\mathrm{~m}^{3} / \mathrm{m}^{2}$. hour & $0,03-0,17$ \\
Operational duration & 24 & hours & \\
Membrane/module area & 55,7 & $\mathrm{~m}^{2} /$ module & $8-70$ \\
Backwash interval & 60 & minute & $30-90$ \\
Backwash duration & 5 & minute & $1-5$ \\
Number of shelves & 2 & units & \\
\hline
\end{tabular}

Source: The results of the author's interpretation and analysis

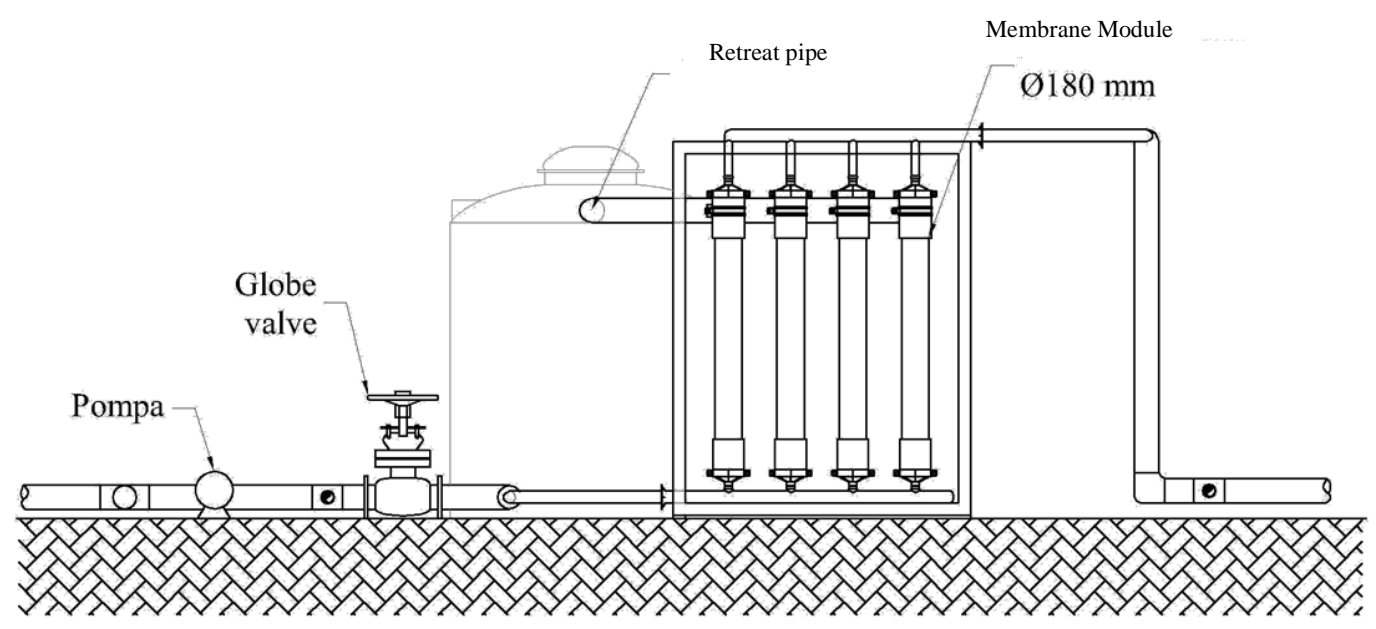

Figure 3. Schematic design of produced water treatment with membrane unit Source: The results of the author's interpretation and analysis

Although ultrafiltration membranes have a very high resistance to fouling, periodic membrane maintenance e.g. backwashing is generally necessary. The water requirement for backwashing can be calculated by considering the flux, duration, and membrane area as below.

Backwash water requirement $=$ flux $\mathrm{x}$ duration of backwash $\mathrm{x}$ membrane area

$=0.137 \mathrm{~m} 3 / \mathrm{m}^{2}$.hour $\times(5$ minutes $\times$ hours $/ 60$ minutes $) \times 440 \mathrm{~m}^{2}=5.049 \mathrm{~m} 3=5049 \mathrm{~L}$

The water tank used to accommodate the residual backwash (retentate) water is set in the form of profile tanks with a capacity of 5,100 liters, available in the market. The tank used is a Penguin brand tank with a General Tank type of 5,100 liters (Figure 4). The tank material is HDPE to ease the movement and to with stand against air pressure. The overall layout of the produced water treatment plan with CPI units, ultrafiltration membranes, and profile tank is shown in Figure 5. The layout or arrangement of the existing treatment facilities and work areas is the main foundation in systematically building a production water treatment plant. 


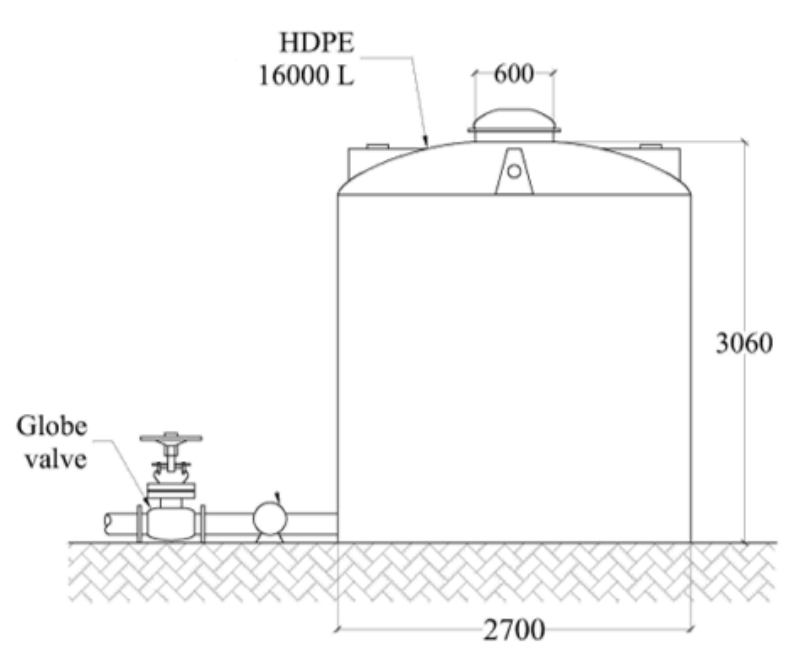

Figure 4. Schematic design of produced water treatment storage with profile tank Source: The results of the author's interpretation and analysis

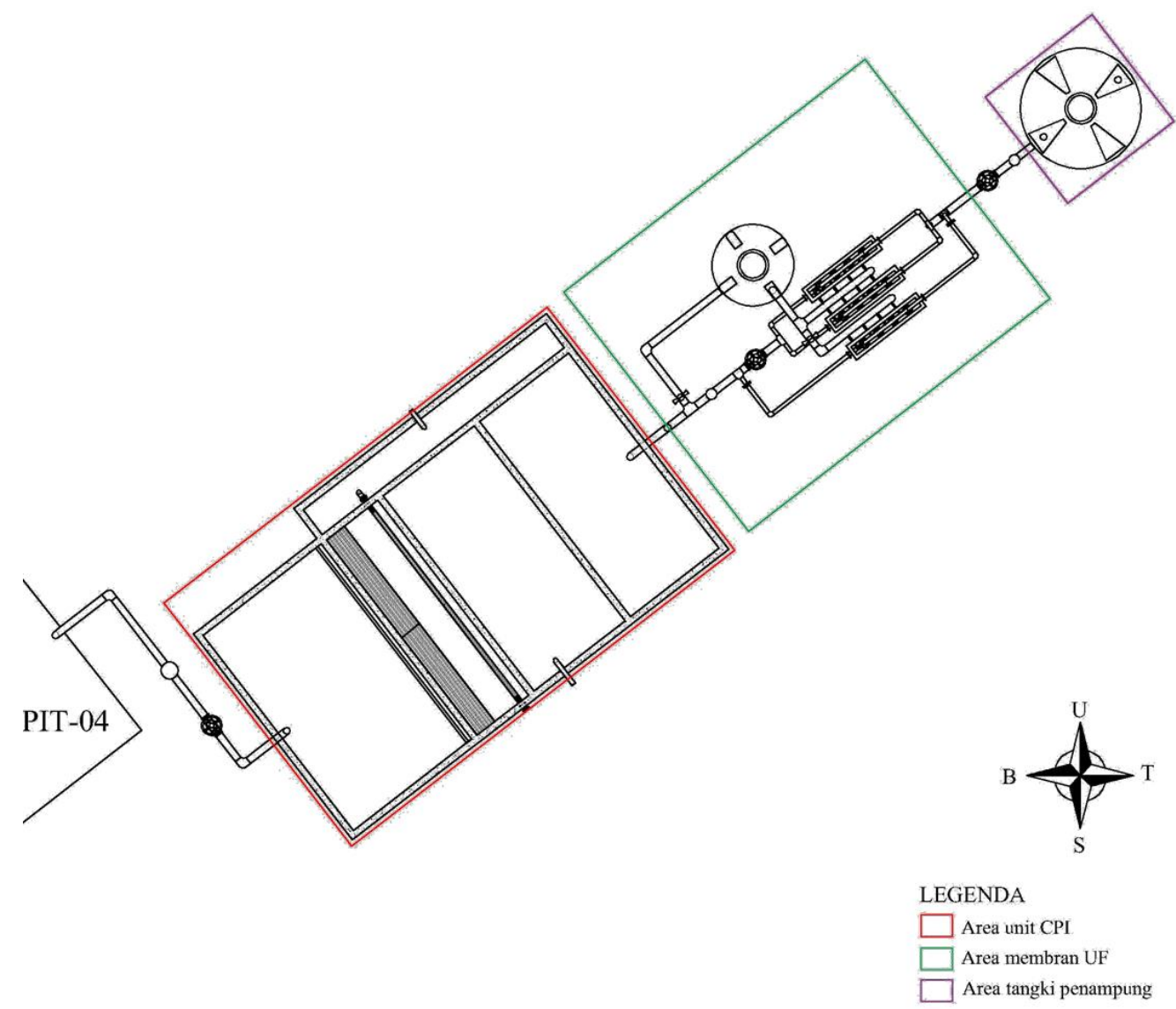

Figure 5. The overall layout of produced water treatment plan with CPI units, ultrafiltration membranes, and profile tank

Source: The results of the author's interpretation and analysis

\section{Conclusion}

Produced water treatment planning with CPI configuration and UF membrane with storage tank requires a total land area of $63.97 \mathrm{~m}^{2}$. The CPI unit has dimensions of $10 \mathrm{~m}$ long, $5.5 \mathrm{~m}$ wide, and $2 \mathrm{~m}$ deep with a land area of $55 \mathrm{~m}^{2}$. The second unit, the UF membrane with a length of $1,919 \mathrm{~m}$ and a diameter of $0.18 \mathrm{~m}$. The membrane modules used were eight modules with a land area of $0.2 \mathrm{~m}^{2}$. The retention tanks and holding tanks have a land area of $3.05 \mathrm{~m}^{2}$ and $5.72 \mathrm{~m}^{2}$, respectively. 


\section{References}

[1] M. A. Firmansyah, Perencanaan Alternatif Pengolahan Biologi pada Instalasi Pengolahan Air Terproduksi di Industri Migas. Bandung: Institut Teknologi Bandung, 2015.

[2] F. C. Dolan, T. Y. Cath, and T. S. Hogue, "Assessing the feasibility of using produced water for irrigation in Colorado," Sci. Total Environ., vol. 640-641, pp. 619-628, 2018, doi: https://doi.org/10.1016/j.scitotenv.2018.05.200.

[3] W. Astono, E. Suswantoro, dan Winda, "Analisis penyebaran minyak dan lemak serta evaluasi unit proses air terproduksi di platform kf star energy (Kakap) ltd," Indones. J. Urban Environ. Technol., vol. 6 (5), hal. 123-131, 2016, doi: 10.25105/urbanenvirotech.v6i5.709.

[4] E. S. Sofiyah and I. W. K. Suryawan, "Cultivation of Spirulina platensis and Nannochloropsis oculata for nutrient removal from municipal wastewater," Rekayasa, vol. 14 (1), pp. 93-97, 2021, doi: 10.21107/rekayasa.v14i1.8882.

[5] I. V. A. Y. Septiariva, I. W. K. Suryawan, and A. Sarwono, "Reactive black 5 (RB5): pengolahan air limbah tekstil dengan adsorbsi menggunakan powdered karbon aktif reactive black 5 (RB5): treatment of textile wastewater by adsorption using powdered activated carbon," vol. 21 (2), pp. 199-205, 2021.

[6] I. W. K. Suryawan, Q. Helmy, S. Notodarmojo, R. Pratiwi, and I. Y. Septiariva, "Textile dye reactive black 5 (rb5) bio-sorption with moving bed biofilm reactor and activated sludge," Indones. $J$. Environ. Manag. Sustain., vol. 5, 2021.

[7] N. Fadhilah, L. Alvin, W. Vembrio, and R. H. Safira, "Modifikasi unit proses dalam peningkatan efisiensi penyisihan amonium modification of process unit to improve ammonium removal efficiency," Jsal, vol. 7, no. 2, pp. 47-56, 2020.

[8] I. G. Wenten, Teknologi Membran dalam Pengolahan Air dan Limbah. Bandung: Institut Teknologi Bandung, 2005.

[9] K. Arnold and M. Stewart, Produced Water Treatment Field Manual (1st Ed.). Gulf Professional Publishing, 2011.

[10] H. Hasnaningrum, B. Ridhosari, and I. W. K. Suryawan, "Planning advanced treatment of tap water consumption in Universitas Pertamina," J. Tek. Kim. dan Lingkung., vol. 5 (1), p. 1, 2021, doi: 10.33795/jtkl.v5i1.177.

[11] M. Rosidi, Perancangan Instalasi Pengolahan Air Limbah (IPAL) Pabrik Kertas Halus PT X Sidoarjo. Surabaya: Institut Teknologi Sepuluh Nopember, 2017.

[12] W. E. Odiete and J. C. Agunwamba, Novel Design methods for Conventional OilWater Separators. Nigeria: Department of Civil Engineering, University of Nigeria, 2019.

[13] Odiete, W. E., \& Agunwamba, J. C. Novel design methods for conventional oil-water separators. Heliyon, 5(5), e01620. 2019.

[14] SWMM City of Tacoma, Chapter 11 Oil Water Separators. Storm Water Management Model. 2012.

[15] M. L. Davis, Water and Wastewater Engineering: Design Principle and Practice. New York: McGraw-Hill Companies, 2010.

[16] Amran, N. A., \& Mustapha, S. N. A. Oil-Water Separation Techniques for Bilge Water Treatment. In Resources of Water. IntechOpen. 2020.

[17] Pratiwi, K. D. S., \& Hermana, J. J. Efisiensi pengolahan limbah cair mengandung minyak pelumas pada oil separator dengan menggunakan plate settler. Jurnal Teknik ITS, 3(1), D5-D9. 2014.

[18] Badan Standardisasi Nasional, Standar Nasional Indonesia 7508:2011 tentang Tata Cara Penentuan Jenis Unit Instalasi Pengolahan Air Berdasarkan Sumber Air Baku. Jakarta: BSN, 2008

[19] Safitri, H. I., \& Aryanti, N. "Teknologi Ultrafiltrasi Untuk Pengolahan Air Terproduksi (Produced Water)". Jurnal Teknologi Kimia dan Industri, vol. 2(4), pp. 205-211, 2020. 